\title{
ИНТЕРПРЕТАЦИЯ
}

\author{
В.П. Перевалов
}

\section{ДВУГЛАГОЛЬНОЕ СКАЗУЕМОЕ. АНАЛИЗ \\ «ЯДРА» ЦЕНТРАЛЬНОГО ПРЕДЛОЖЕНИЯ \\ СТИХОТВОРНОЙ ПОВЕСТИ А.С. ПУШКИНА}

\begin{abstract}
Аннотация. Статья посвящена исследованию историософских взглядов А.С. Пушкина. Осмысление Поэтом судьбы Российской Империи выявляется путём анализа особенностей образности его произведения «Медный всадник. Петербургская повесть» (1833), которое стало важнейшим текстом духовной культуры в нашей стране. С момента опубликования пушкинский шедевр вызвал и до сих пор вызывает огромное число разных откликов и множество противоречивых концептуальных интерпретаций. Нарастающие различия становятся избыточными, заслоняют собой текст оригинала и размывают собственно авторскую позицию.

В условиях чрезвычайно "расширившейся Вселенной» напрашивается подход к пониманию идейного смысла «Медного Всадника» противоположным образом. Содержательному развёртыванию пушкинского произведения должно предшествовать его предельное сжатие, нацеленное на установление центрального предложения в нём, а затем и на слово-«ядро» в самом центре.

Таким словом-«ядром», выражающим противоречивую динамику мироустроения, парадоксально оказывается сказуемое "стоит» в последнем предложении 1 части «Медного Всадника». Его необычность привлекала внимание нескольких пушкинистов, но решающего значения они ему не придавали. На мой взгляд, первостепенность и оригинальность его образности порождается значениями двух разных глаголов: «стоИть» и «стоять». Трудность полного усвоения содержания ключевого сказуемого заключается в том, что оно, с одной стороны, вызывает сбой поэтического размера текста и смену его на прозу, а с другой, объединение обоих в одно челое. Тем самым в самом истоке системы образов произведения обнаруживается взаимодополнительность поэтического пласта с прозачческим, бытового с фантастическим, физического с метафизическим.

В данной трактовке приверженность Пушкина России как великой державе (Империи) несомненна и органически сочетается с его общей, в целом положительной оценкой деяний Петра I, в которой Поэт призывает его наследников особо почитать и культивировать милосердие.
\end{abstract}

Ключевые слова: глагол, сказуемое, образ, многозначность, поэзия, проза, творчество, «Медный Всадник», А.С. Пушкин, «Капитанская дочка».

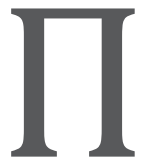
роизведение А.С. Пушкина «Медный Всадник. Петербургская повесть» с момента опубликования вызвало и до сих пор продолжает вызывать огромнейшее число разных откликов и множество противоречивых толкований. Что неоспоримо свидетельствует о глубинной, сокровенной значимости поднятых в нем проблем развития России, их непреходящей актуальности в духовной жизни страны. Опыт истории показывает, что каждая культурная эпоха вступает в диалог с Поэтом по-своему, воспринимает поэму-повесть на свой лад, отдавая предпочтение необходимым и достаточным (для себя «всеобщим») выводам - иным, чем у предшествующих и последующих собеседников классика.

В известной мере разнообразие «моих Пушкиных» соответствует реальной открытости их гениального «прообраза» для дискуссий, его «всемирной отзывчивости» на новые веяния времени. Следовательно, и не абсолютной окончательности предложенных им решений.

Вместе с тем, нарастающее разнообразие концептуальных интерпретаций становится избыточным: ответы все дальше расходятся друг от друга, трактовки героев и событий «Медного Всадника» выпадают из контекстуального единства с други- 


\section{Филология: научные исследования 4(16) 2014}

ми произведениями автора. Быстро прибывающее наводнение своим бурлящим шумом заглушает собственно пушкинскую речь, заслоняет собой и угрожающе размывает его позицию в классическом творении русской культуры.

Предлагаемые ниже размышления подходят к осмыслению пушкинского шедевра с иной стороны - его предельного сжатия. В начале до установления в стихотворной повести одного - композиционного и содержательного - центрального предложения, а затем до выделения в нем одного слова-ядра. Им должно быть сказуемое, поскольку динамичная структура образов «Медного Всадника» выстраивается на оси глагольных связей и отношений.

Указанным условиям удовлетворяет предложение, завершающее первую часть повествования, то есть занимающее место в середине его композиции.

И, обращен к нему спиною,

В неколебимой вышине,

Над возмущенною Невою

Стоит с простертою рукою

Кумир на бронзовом коне.

(Акад. V стр. 142)

Вряд ли есть концептуальное исследование «Медного Всадника», не обратившее на него серьёзного внимания. Но уровень предложения не дает ничего нового для решения поставленной задачи. Однако, на микроуровне отдельных слов его сказуемое «стоит» неожиданно вступает в явное противоречие с моей рабочей гипотезой о главном источнике образной динамики. Скорее всего, из-за очевидного здравому смыслу парадокса в слове «стоит» большинство исследователей не пыталось уловить образ движущегося нечто. «Стоит» - значит недвижим. Его необычность привлекла внимание нескольких пушкинистов, но решающего значения они ему не придавали ${ }^{1}$.

Крайне непростая проблема места и роли движения в космическом упорядочивании мира интересовала А.С. Пушкина:

Движенья нет, сказал мудрец брадатый.

Другой смолчал и стал пред ним ходить.

Сильнее бы не мог он возразить;

1 См.: Благой Д.Д. Мастерство Пушкина. М., 1955. С. 211212; Макогоненко Г.П. Творчество А.С. Пушкина в 1830е годы (1833-1836). Л.: Художественная литература, 1982. С. 178-180; Красухин Г.Г. Доверимся Пушкину: Анализ пушкинской поэзии, прозы и драматургии. М.: Флинта, Наука, 1999. C. 209-210.
Хвалили все ответ замысловатый. Но, господа, забавный случай сей Другой пример на память мне приводит: Ведь каждый день пред нами солнце ходит, Однако ж прав упрямый Галилей. (Акад. II стр. 381).

Применительно к обществу Пушкин формулирует проблему соотношения покоя и движения (изменения) так:

Stabilité - première condition du bonheur publique.

Comment s'accommode-t-elle avec la perfectibilité indéfinie?

Перевод:

Устойчивость - первое условие общественного благополучия. Как она согласуется с непрерывным совершенствованием? (франц.)

Акад. 12. С.196, 482

Согласно научным представлениям Нового времени покой неотличим от равномерного прямолинейного движения. Но совместим ли он с противоречивостью и кривизной изменений? Возможно ли в их разломах и крушениях «стоять»?

Доверимся крылатому пушкинскому выражению, согласно которому в открытьях чудных духа просвещенья «гений - парадоксов друг» и вопреки общему мнению рискнем словить в «стоит» глагольные значения, единство различий которых образует (оба-в-раз) исток и силы сказывания. Иначе говоря, попытаемся понять Поэта, глаголом жгущего сердца людей.

Сказуемое центрального предложения поэмы, на мой взгляд, должно пониматься и осмысленно признаваться как единство разных значений не одного, а двух глаголов.

В семантике сказуемого «стоит» противоречиво сложены, т.е. постоянно борются, сотрудничают, живут составляющие двух глаголов «стоять» и «стоить». Первая соответствует ямбическому размеру поэмы, в «поэзии гармонической точности» воспроизводит реальность так, как она дана здравому смыслу в чувственно-(умном) восприятии: памятник Петру стоит на и над залитой Потопом городской площади.

Вторая составляющая значений «стоит» от глагола «стоить» непосредственному восприятию не дана. Более того, она внеразмерна ямбу, сбивает поэтический ритм на прозаический. Зачем она, хромо- 


\section{Интерпретация}

ногая, нужна? Не является ли надуманным привнесением интерпретатора в пушкинский текст?

Если исключить прозаическую составляющую значений из центрального сказуемого поэмы, то и поэтическая его составляющая опростится до однозначности - до неподвижности в вертикальном положении. Тогда прав Евгений, обвинивший Отца-основателя в том, что он бездействовал в смертельной схватке его детища и продолжателей начатого им чудотворного строительства с взбунтовавшейся Невой. По сути не столь важно «сидел» или «стоит» («стоял» и «будет стоять») Император в схватке роковой он был неподвижен, сохранял покой, равнодушную пассивность «над» ужасом бед и гибели своих подданных. (Как эпикуровские боги, погружённые в наслажденье самолюбованья в меж мировых пространствах). Тогда бунт против него не столь бессмыслен.

Позиция Пушкина, автора не совпадает с позицией героя. Необходимость прозаического осмысления поэмы, след., и центрального сказуемого в ней, подчеркнута им в подзаголовке произведения: «Петербургская повесть». Стихи и проза образуют сложное единство, выходящее за пределы каждого из них, предполагающее дополняющее прочтение поэтической гармонии сверхпоэтической прозой; «иным», но «своим» в потустороннем.

«Стоять» в вертикальном положении, на ногах, во весь рост значит быть устремленным снизу вверх, с земли к небесам. Не быть слабым в коленках, не стоять на них униженно пред ворогом. В этих и других примерах физическое переплетается с метафизическим.

Если сбиться с поэтического размера и подключить к осмыслению сказуемого «стоит» значения, вытекающие из глагола «стоить», то обвинение Петра Евгением в пассивности, неподвижном, равнодушном ко всему остальному самодовольстве неистинно. Его ложь явит себя в стремительном бегстве бунтаря через мгновение после объявления о начале своего наступления. Ложно оно и ретроспективно. Во-первых, Евгений не видит Всадника. Пред ним «вода и больше ничего» (ближайший контекст приведенного выше центрального предложения). Его сознание оказывается в самом-самом начале Творения мира. В первом из шести дней Творения Дух носился над водою до отделения света от тьмы, дня от ночи (Бытие. Гл. 1, 1-5). Сознание же Евгения как раз в этот момент охвачено сомненьем и отрицаньем, т.е. движется в обратном созиданию направлении, оказывается на грани небытия - Ни- что. Во-вторых, основание Града «под морем» - это суждение и оценка сделанного Петром I Евгения. Сам «строитель чудо творный» задумывал «твердо стать при море».

Итак, если не отождествлять свою позицию с бунтующим Евгением, то значения глагола «стоит» - сложное, противоречивое единство двух разных глаголов «стоять» и «стоить», включающее в себя и «прерыв постепенности», «скачок» из поэтической размерности речи в ее прозаическое течение. «Стоять» во весь рост - сидя (-привстав) на коне (вздыбленном) - в грозный час смертельной опасности значит быть активным борцом с сильнейшим противником. Это дорогого стоит. (Ритмический сбой обеспечивает «органическое» превращение значений одного глагола в значения другого, их переливающееся, проникающее в свое иное, взаимодействие, образующее постоянно волнующее многоразличное единство. Он же, сбой-стык, апеллирует к вниманию и активному соучастию читателя в освоении идеи поэмы, выходящему за инерцию следования чарующей магии пушкинского стиха).

На чьей стороне Пушкин, автор повести Градской? В первой части поэмы он - в отличие от Евгения - видит Императора среди затопленной бушующими водами площади. Через и в физическом видении вертикально стоящего (привставшего на вздыбленном коне без седла и без шпор) над Потопом Всадника автор зрит в метафизический корень - в на-СТО-ящее, в нисходящую из «неколебимой вышины» активность Исполина, обуздывающего Хаос. С Петром, за ним и под его главенством в борьбе за усмирение разрушающей результаты міростроительства Невы участвуют ожившие в час грозной опасности мраморные львы, сторожевые. Не безучастен к разразившемуся бедствию ужасному и неподвижно сидящий на балконе Зимнего дворца Александр I: он повелел своим ближайшим подчиненным о посильной помощи тяжко страдающим людям. Лишь Евгений, столь же неподвижно водрузившись на одном из львов, то есть на передовом крае смертельной схватки, совершенно бездействует: всецело погружен в переживание оберега своего счастья, в какой-то момент омраченного духом сомнения и отрицания смысла божьего Творения. В общем и целом на пике Потопа герой пассивно, подсознательно примыкает к стану борцов за умиротворение Стихий, следовательно, приемлет (хотя бы соблюдая нейтралитет) и Петра как Властелина Судьбы. 


\section{Филология: научные исследования 4(16) 2014}

На мой взгляд, последняя тень сомнений в том, что Пушкин вкладывает двуглагольные значения в центральное сказуемое поэмы «стоит», исчезает при непосредственном сравнении последнего предложения первой части «Медного Всадника» с Вступлением. В самом начале повествования, 130 лет назад,

«На берегу пустынных волн

Стоял он дум великих полн»...

Думы міростроителя в мире стихий, то природных (в народе блага успокоенных, устойчивых, то хаосящихся, разрушительно гибельных, были о том, чтоб «твердо стать при море» ради торговли добром со всем честным миром и назло соседям недобрым. Таковы реалии: и сужденное природой трудное и скудное для жизни место, и вековая история родной стороны.

Величие дум Петра превышало не только обычное для земных свершений людей, но и сверхобычное. Задуманное Градостроительство, как чудо выходило за пределы Земного, держалось замковым камнем (энергией духа Петра) на Небесах как Дух, его великие думы летали над бездной.

Основная часть Вступления раскрывает в общем и во многих деталях воплощение дум Отцаоснователя, оно пронизано крылатым 5-кратным «люблю» автора к памятнику, который Петр воздвиг себе. Не стоит задерживаться на том, о чем неоднократно писали. Обратим внимание, что Евгений в противоположность автору не испытывает к Граду и его зачинателю восторженных чувств, хотя предки обоих пострадали от гонений и казней сего гневного царя, после чего знатный род пришел в упадок (или ветвь каждого из них в нем).

Прославление великих деяний Петра в чудостроительстве заканчивается в предпоследнем фрагменте Вступления (в последнем осуществляется переход к основной части повести, мажорные интонации обрываются предуведомлением: «печален будет мой рассказ»). Завершая свое восторженное любование содеянного первым Императором, сподвижниками и продолжателями его Державного дела, Пушкин высказывает надежду и веру в непреходящее, вечное существование государства Российского.

Красуйся, град Петров, и стой

Неколебимо как Россия.

И тут же возвращается к самому началу - к борьбе людей с тенденциями разрушения и гибели сущего в Стихиях: это - возврат «якобы к старому», ибо стихия Воды побеждена, Нева стала частью города, оделась в гранит и т.д. Но умирится ли она навсегда со своим новым, цивильным положением? Забудет ли вольнолюбивая в своих волнах река, какой ценой досталась ей надприродная краса? А волны финские, морские, неградские? Увещевает их Поэт, забывший вражду представителей своего рода с Петром, смирившийся с обидами, нанесенными им Строителем:

\section{Да умирится же с тобой \\ И побежденная стихия; \\ Вражду и плен старинный свой \\ Пусть волны финские забудут \\ И тщщетной злобою не будут \\ Тревожить вечный сон Петра!}

$$
\text { (Акад. V стр. 137) }
$$

О том, что не все последовали примеру Поэта и среди стихий, и среди людей, рассказывается в основной части поэтической повести. Но из уже проанализированных выше значений «стоит», «стоял», «стой», глаголов Вступления и конца Первой части достаточно ясно и твердо определена позиция автора. Он последовательно отстаивает сторону Петра (камня строительного) в противоборстве с хаосящейся Стихией: сперва природной, а затем и социальной. По определению: Поэт - созидатель, стихотворец. Герой же повествования в первой части намеревается принять, действенней соучаствовать в жизни победившего петровского Града: семья обязывает. Среди Потопа он на стороне Императора, хотя пассивно, незряче, с сомнением даже в божественном Творце. В начале второй части, он активно противодействует потопу: гонится за его отливом, переплывает через бурные (чуть спавшие с пика) волны на брег обетованный. Но там, не устояв перед бесследным исчезновением в бунтующих волнах Мечты своей, Евгений сходит с ума. Год он, «ни зверь, ни человек» носит в себе шум катастрофы, а когда в нем прояснились страшно мысли, мир (уж замиренный) предстал безвыходно ужасным. Уподобившись хаосящейся стихии, он перешёл на её сторону и восстал против

«того,

Кто неподвижно возвышался

Во мраке медною главой,

Того, чьей волей роковой

Под морем город основался...

\section{(Акад. V стр. 147)}

Восприятие героя искаженно, оценки (выбор значений и придание им объединяющего их смысла) ошибочны. Евгений приписывает, несмотря на существенную разность ситуаций, Петру свою 


\section{Интерпретация}

возвышенно равнодушную (ровно бездушную) ко всему остальному неподвижность; великие думы о преодолении мрака невежества и запустения подменяет беспросветным мраком упрямства медного лба; волю государя, сообразующуюся с нуждами страны, ее природой, климатом и историей с прихотливым произволом самовластия рокового, основавшего город под морем... При этом заблуждения, ошибки (и ложь) усугубляются верой в догму просветительской схемы о том, что замысленное - особенно абсолютным монархом - воплощено в реальность неукоснительно, точь в точь.

То, что его злоба тщетна, Евгений убедился от одного взгляда разгневанного Царя. Удавка «Ужо», которой герой возжелал устранить чудотворного Строителя, оказалась безопасным шипением ужа, пшикалкой. Иным исход противоборства с мощным властелином судьбы быть не мог. Евгения обуяла паника, он стремглав пустился в бегство.

Как реагировал на это Петр Великий? Это - особый вопрос. Вопрос о наказании и/или прощении преступившего закон, покусившегося на верховную власть. Доступно ли милость к падшим душе грозного, подчас гневного Державца полумира? Сие сказывает вторая часть печальной петербургской повести.

В сказуемом «стоит» заключен не только неподвижный, неизменный покой, но и образ действия созидания, защиты уже построенного міра в мире стихий. Покой как «вечный сон» не исключает действенного бодрствования, а предполагает переход в противоположность, активизируется в годину (час) грозных испытаний. На стоянии Кумира Отца-основателя «в неколебимой вышине» весь сотворенный им свет держится. Стоит без слабости в дрожащих, согнутых коленках, не униженно на коленях, не ударившись в грязь лицом. Не боясь никого и ничего, яростно, гневно стоит против сил злобы, разрушения и смерти за всех своих, за родное, народное. Как тут не вспомнить:

«Вставай страна огромная,

Вставай на смертный бой

С проклятой силой темною,

С фашистскою ордой!

Пусть ярость благородная

Вскипает как волна

Идет война народная

Священная война».

Спустя 100 лет после смерти, после погружения в вечный сон Петр Великий «живее всех живых». В тревожный для его детища час он не мог не проснуться, не мог не постоять всей своей исполинской мощью за своих и себя - за наше всё.

В «словаре языка Пушкина отмечено употребление им слов: «стоить» - 87 раз; «стоять»360 раз (плюс «стоя» - 4, «стоячий»- 1) 2 . Рассмотрим некоторые из них подробнее.

Временем написания первой глав «Евгения Онегина» (9 мая - 22 октября 1823 г.) датируется стихотворение «Кто волны вас остановил». В нем усыпление бурной души, ее духовного порыва в реализации возвышенных целей, Идеала представлено в картине неожиданного успокоения казалось бы неизбывной изменчивости природных стихий.

Кто, волны, вас остановил,

Кто оковал ваш бег могучий,

Кто в пруд безмолвный и дремучий

Поток мятежный обратил?

Чей жезл волшебный поразил

Во мне надежду, скорбь и радость

И душу бурную

Дремотой лени усыпил?

Взыграйте, ветры, взройте воды,

Разрушьте гибельный оплот!

Где ты, гроза - символ свободы?

Промчись поверх невольных вод.

(Акад. II стр. 258, 1072)

Это произведение, запечатлевшее кризис мировоззрения Пушкина, при его жизни напечатано не было. Размышления над проблемой утраты романтического Идеала молодости (возвышенного, вселенского, бурно и грозно обновляющего привычную жизнь людей и общества) Поэт продолжил во многих своих произведениях разного жанра. Например, в стихотворении «Буря» и отрывках из «Путешествия Онегина».

\section{БУРЯ}

Ты видел деву на скале

В одежде белой над волнами

Когда, бушуя в бурной мгле,

Играло море с берегами,

Когда луч молний озарял

Ее всечасно блеском алым

И ветер бился и летал

С ее летучим покрывалом?

Словарь языка Пушкина в 4-х томах. М.: Азбуковник. 2000. T. 4. C. $390-391,403-405$. 


\section{Филология: научные исследования 4(16) • 2014}

Прекрасно море в бурной мәле

И небо в блесках без лазури;

Но верь мне: дева на скале

Прекрасней волн, небес и бури ${ }^{3}$.

(Акад. II стр. 390)

В грозовой мгле, озаряемой молниями, стоит на скале над штормовым, буйно играющим с берегами морем Дева в летучем белом покрывале. Eе образ, концентрированно выражает восторг и преклонение Поэта перед самым прекрасным и благим в Природе, включая в нее и людей, и их общежитие. Дева - полное и чистое, совершенное воплощенье возвышенных чаяний и сердечных упований вольности святой, жгучее нетерпение дня в уже всходящей заре пленительного счастья. То есть докризисный (до второй половины 1822 г.) идеал в развитии пушкинского мировоззрения. В год написания «Бури», 1825, весны моей мечтанья в прошлом: «Ты видел....» Но не исчезли из души бесследно: «Верь мне...» (Ср.: «Товарищ верь взойдет она...» (1818)). Верь мне: и без буйства природы (романтической обстановки) и в повседневном наряде и делах привычных Дева-Свобода прекрасней и дороже всего на свете. Надо всем стоит, на-СТОстоящая META (физика).

В «Путешествии Онегина» Пушкин возвращается к осмыслению пройденного его музой. Среди воспоминаний юга на первом месте Таврида.

В ту пору мне казались нужны

Пустыни, волн края жемчужны,

И моря шум, и груды скал,

И гордой девы идеал,

И безыменные страданья...

(Акад. VI стр. 200)

В ту пору общественно-гражданское свободолюбие Поэта тесно переплеталось с «утаенной любовью» (Ср.: «Как ждет любовник молодой Минуты верного свиданья»). Он очень-очень надеялся, что в Тавриде, встретившей его «при свете утренней Киприды», тайное в отношениях с Ольгой Потоцкой станет явным, счастливо увенчается блеском брачного наряда.

Какой во мне проснулся жар!

Какой волшебною тоскою

3 Кардаш Е.В. Буря - Пушкинская энциклопедия. Произведения. Вып. 1. А - Д. Нестор - История. СПб., 2009. С. 194196. (Там же - библиография).
Стеснялась пламенная грудь!

Но, Муза! прошлое забудь.

В 1820 г. Ольга приехала в крымское именье Потоцких, расположенное рядом с Гурзуфом, когда Поэт его покинул. Они встретятся в Одессе через три года в совсем других обстоятельствах.

Какие б чувства ни таились

Тогда во мне - теперь их нет:

Они прошли иль изменились...

Мир вам, тревоги прошлых лет!

Другие дни, другие сны;

Смирились вы, моей весны

Высокопарные мечтанья,

И в поэтический бокал

Воды я много подмешал.

Мой идеал теперь - хозяйка,

Мои желания - покой,

Да щей горшок, да сам большой.

(Акад. VI стр. 200 - 201)

Да и смириться Деве гордой надо -

Стоит Державный Всадник в центре Града.

\section{КАВКАЗ}

Кавказ подо мною. Один в вышине

Стою над снегами у края стремнины;

Орел, с отдаленной поднявшись вершины,

Парит неподвижно со мной наравне.

Поэт занимает высочайшее место в мире дольнем, рост - дар его касается небес надлунных, неизменных. Горнее - ореол Поэта, стихотворца; лишь неподвижное парение орла, царственной птицы, с ним наравне.

Но, взлетев недосягаемо высоко, Поэт не забывает земное, не стремится на более дальние небеса, где о покинутом стирается и исчезает память. Напротив, единым, панорамным взором он обозревает, сдвигая фокус зрения сверху вниз, всё существующее под ним.

Отселе я вижу потоков рожденье

И первое грозных обвалов движенье.

Здесь тучи смиренно идут подо мной;

Сквозь них, низвергаясь, шумят водопады;

Под ними утесов нагие громады;

Там ниже мох тощий, кустарник сухой;

А там уже рощи, зеленые сени,

Где птицы щебечут, где скачут олени.

А там уж и люди гнездятся в горах, 


\section{Интерпретация}

И ползают овцы по злачным стремнинам,

И пастырь нисходит к веселым долинам,

Где мчится Арагва в тенистых брегах...

Доступны поэтическому видению не только наземные и надземные явления, но и явления подземные, не только уравновешенные движенья, но и враждебные умиротворенности отступления, тайные и открытые.

И нищий наездник таится в ущелье,

Где Терек играет в свирепом веселье;

Играет и воет, как зверь молодой,

Завидевший пищу из клетки железной;

И бьется о берег в вражде бесполезной

И лижет утесы голодной волной...

«Есть» потому и называется «миром», что эта сторона его, эта тенденция в нем устойчиво преобладает над «хаосом», уподобляется Бытию.

Вотще! нет ни пищи ему, ни отрады:

Теснят его грозно немые громады.

(Акад. III стр. 196)

Время от времени на сторону созидания мира света, гармонии и любви покушается злобно темная, разрушительная сторона «Есть», Стихии хаосятся.

\section{ОБВАЛ}

Дробясь о мрачные скалы,

Шумят и пенятся валы,

И надо мной кричат орлы,

И ропщет бор,

И блешут средь волнистой мглы

Вершины гор.

Оттоль сорвался раз обвал,

И с тяжким грохотом упал,

И всю теснину между скал

Загородил,

И Терека могущий вал

Остановил.

Вдруг, истощась и присмирев,

О Терек, ты прервал свой рев;

Но задних волн упорный гнев

Прошиб снега...

Ты затопил, освирепев,

Свои брега

И долго прорванный обвал

Неталой грудою лежал,

И Терек злой под ним бежал.

И пылью вод

И шумной пеной орошал

Ледяный свод.

И путь по нем широкий шел:
И конь скакал, и влекся вол, И своего верблюда вел

Степной купец,

Где ныне мчится лишь Эол,

Небес жилец.

(Акад. ІІІ стр. 197)

Во время польского восстания 1830-1831 годов Пушкин посетил Казанский собор в Петербурге, где упокоен М.И. Кутузов.

Перед гробницею святой

Стою с поникшею главой..

Все спит кругом; одни лампады

Во мраке храма золотят

Столпов гранитные громады

И их знамен нависший ряд.

Под ними спит сей властелин,

Сей идол северных дружин,

Маститый страж страны державной,

Смиритель всех ее врагов,

Сей остальной из стаи славной

Екатерининских орлов.

В твоем гробу восторг живет!

Он русский глас нам издает;

Он нам твердит о той године,

Когда народной веры глас

Воззвал к святой твоей седине:

«Иди, спасай!» Ты встал - и спас...

Внемли ж и днесь наш верный глас,

Встань и спасай царя и нас,

О старец грозный! На мгновенье

Явись у двери гробовой,

Явись, вдохни восторг и рвенье

Полкам, оставленным тобой!

Явись и дланию своей

Нам укажи в толпе вождей,

Кто твой наследник, твой избранный!

Но храм - в молчанье погружен,

И тих твоей могилы бранной

Невозмутимый, вечный сон...

(Акад. III стр. 267 - 268)

Призыв Поэта к спасителю Отечества в грозу 1812 года очнуться от вечного сна, встать ради повторения своего подвига остается без ответа. Опасность для России не столь велика? Избранник среди нынешних вождей выдвинется в ходе борьбы сам? Видно, черед действовать великому Старцу еще не настал.

Отметим, что в перечне характеристик М.И. Кутузова «идол» не содержит никаких оттенков отрицательности. 


\section{Филология: научные исследования 4(16) • 2014}

Стояние и горькой истины открытье, Лариной Татьяны

(Евгений Онегин», 7 гл. Х111-ХХУ1. Акад. У1 С. 144-150).

Потопа страшных разрушений и утрат не выдержал Евгений, без Параши в миру не устоял. А Татьяна? Когда доставшиеся ей судьбою испытанья пополнились отъездом из деревни Онегина, как вела себя она? Ведь это про нее: не по-хорошему мил, а по милу хорош... А тут еще и с Оленькой, покинувшей родимое гнездо за мужем вслед, невольником военной доли навек разлука.

\section{Гл. 7. $X 111$}

Как тень она без цели бродит, то смотрит в опустелый сад... Нигде, ни в чем ей нет отрад, И облегченья не находит Она подавленным слезам, И сердце рвется пополам.

\section{$X I V$}

И в одиночестве жестоком

Сильнее страсть ее горит,

И об Онегине далеком

Ей сердце громче говорит.

Она его не будет видеть;

Она должна в нем ненавидеть

Убийцу брата своего;

Поэт погиб... но уж его

Никто не помнит, уж другому

Его невеста отдалась.

Поэта память пронеслась

Как дым по небу голубому,

О нем два сердца, может быть,

Еще грустят... На что грустить?..

Уж за рекой, дымясь, пылал Огонь рыбачий. В поле чистом, Луны при свете серебристом, В свои мечты погружена, Татьяна долго шла одна. Шла, шла. И вдруг перед собою

С холма господский видит дом, Селенье, рошу под холмом И сад над светлою рекою. Она глядит - и сердце в ней Забилось чаще и сильней.
Одолев смущенье, едва дыша Татьяна с возвышенности сходит к дому, где не без драки мальчишки распугали испугавших ее псов, «Взяв барышню под свой покров».

Ср. злое отношение детей к умалишенному Евгению («Медный Всадник») и к юродивому Николке («Борис Годунов»).

«Увдеть барской дом нельзя ли?» Спросила Таня. Поскорей

К Анисье дети побежали...

И дверь пред ними отворилась,

И Таня входит в дом пустой,

Где жил недавно наш герой.

Татьяна взором умиленным

Вокруг себя на все глядит,

И все ей кажется бесценным,

Все душу томную живит

Полумучительной отрадой:

И стол с померкшею лампадой,

И груда книг, и под окном

Кровать, покрытая ковром,

И вид в окно сквозь сумрак лунный,

И этот бледный полусвет,

И лорда Байрона портрет,

И столбик с куклою чугунной

Под шляпой с пасмурным челом,

С руками, сжатыми крестом.

\section{$X X$}

Татьяна долго в келье модной

Как очарована СТОИТ. (Выделено мною. ВП)

По «странному сближению в знаменитом четверостишии об этом пушкинском романе Анна Андреевна Ахматова использовала тот же глагол:

И было сердцу ничего не надо,

Когда пила я этот жгучий зной...

«Онегина» воздушная громада,

Как облако, стояла надо мной.

В злую для него минуту объяснения в любви Татьяне N, замужней, но продолжающей любить его, «с колен поднимется Евгений» (В.В. Набоков). C началом мук открытия окна новых, небывалых возможностей настоящей жизни в себе заглавным героем Поэт прощается с ним «надолго, навсегда».

Татьяна очарованно стоит. Сойти не хочет: дом её мечты - сравни с неверящим своим глазам Евгением: «Где дом? Вороты где?» 


\section{Интерпретация}

«...очнулась поздно, пилигримке молодой Пора, давно пора домой». Но отчего волненье, «Не без того, чтоб не вздохнуть», приходится наедине с собой скрывать Татьяне? Не оттого ли, что вдруг ощутила (кольнуло в сердце резко), путь к родительскому крову как обратный, не единственный? Что отныне Дом ее и тут, в опустелом замке? Как ей, хозяйке очага, поочередно, через день - с утра, с утра пораньше не навещать оставленную им сень? Все три исключенья заодно: уж замуж невтерпеж. Где же ты, где?

И в молчаливом кабинете,

Забыв на время все на свете,

Осталась наконец одна,

И долго плакала она.

$(X X 1,5-8)$.

Книги поначалу - предлог, оправдание для ключницы своих вторжений в чужое жилище. Первое, что пришло в смятенную волнением души голову:

«Потом за книги принялася.

Сперва ей было не до них».

Но не из ниоткуда и в никуда безосновательным случаем: книгам всегда почет и уважение в голове завзятого книгочея. В плену книжном сказалось родство Татьяны и Евгения (опыт разный и общее отношение, конечно, иное). Пролив потоки слез, принялась за чтенье жадною душой: в глубоком, более полном и верном понимании Евгения ей видится берег спасения от горького Потопа одиночества неразделенной Любви. Покинутый им книжный край стал ею осваиваться, обустраиваться в Рай (Сад) общий обоим, цветущий, плодоносный. Знание возлюбленного должно помочь, нет даровать Знатность счастья их союза, уз земных и небесных. Ей открывался мир иной. Выбор книг Евгения Татьяне показался странным. Два-три романа ужасными:
В которых отразился век
И современный человек
Изображен довольно верно
С его безнравственной душой,
Себялюбивой и сухой,
Мечтанью преданной безмерно,
С его озлобленным умом,
Кипящим в действии пустом.

И начинает понемногу

Моя Татьяна понимать

Теперь яснее - слава богу -
Того, по ком она вздыхать Осуждена судьбою властной: Чудак печальный и опасный, Созданье ада иль небес, Сей ангел, сей надменный бес, Что ж он? Ужели подражанье, Ничтожный призрак, иль еще Москвич в Гарольдовом плаще, Чужих причуд истолкованье, Слов модных полный лексикон?.. Уж не пародия ли он?

\section{$X X V$}

Ужель загадку разрешила?

Ужели слово найдено?

Если верно, если истина не изменится, то знание обещает Татьяне знатные испытания. Иль Знамена, подобру-поздорову, пора сложить? Поменять на другие или беззнаменно жить? Да то не жи-ЗНА, то жись вне мет (-«Зато без смерти!»- козыряла См...b).

Часы бегут; она забыла,

Что дома ждут ее давно...

В гнезде родном о доли дочери старшой старушка мать и два соседа и так, и сяк вели беседу и на ярмарку невест решили здраво девицу отвесть. В Москву. А здесь «Буянов сватался отказ». Опасному соседу поделом. Тут ясно все, без сомнений верно. Но, вот незадача так незадача:

«Ивану Петушкову - тоже».

С этими завсегдателями в доме Лариных появляется и исчезает в романе еще один заметный персонаж.

Гусар Пыхтин гостил у нас;

Уж как он Танею прельщался,

Какмелким бесом рассыпался!

Я думала: пойдет авось;

Куда! и снова дело врозь.

Позвольте полюбопытствовать: Вы никого не узнаете в гусаре Пыхтине? По мне - это добродушно-ироничное автоотражение Пушкина, его постоянных признаний в любви к милому идеалу. Мечтал ли с юности лицейской Александр о военной службе именно гусарской? А то! А от балов и танцев был без ума?! По воспоминаниям (не добрым) сокурсника Модеста Корфа не пыхтел ли Пушкин, рьяно увиваясь за девицами и дамами в свете? Так что ухажёр-гусар, какой надо ухажёр. Жаль, пострелу приспел не тот авось (как улану с Ольгой). Да за автора небось: свою будущую тёщу 


\section{Филология: научные исследования 4(16) • 2014}

«как-нибудь» совместно с невестой он переможет. Все три богатыря - авось, не бось и как-нибудь - на заставе русской стоят.

Той же осенью 1833 года Пушкин написал «Сказку о рыбаке и рыбке». В ней глагол «стоит» играет роль моста, выводящего стремительно возрастающие желания старухи за пределы света, в котором она жила до сих пор, в том числе «ровно тридцать лет и три года» женой бедного рыбака.

После передачи волшебнице-рыбке 2-го пожелания-наказа старухи возвратился старик к своей землянке.

«А землянки нет уж и следа;

Перед ним изба со светелкой, С кирпичною, беленою трубою,

С дубовыми, тесовыми вороты.

Старуха сидит под окошком ${ }^{5}$,

На чем свет стоит мужа ругает 6 .

«Дурачина ты, прямой простофиля!

Выпросил, простофиля, избу!

Воротись, поклонися рыбке:

Не хочу быть черной крестьянкой,

Хочу быть столбовою дворянкой».

(Акад. Том 3 стр. 536).

Дальше больше и выше, все быстрей и быстрее. Когда же взалкает она, Владычица света сего, дальнего, стать в потустороннем мире, горнем, наивысшей Богиней, а волшебную благодетельницу свою пожелает определить в слугу на посылках. Т.е. чтобы рыбка сама собственное достоинство чудесное неслыханно, невиданно и немыслимо унизила, тогда гордыня ее непомерная рухнет вниз. Вмиг падет старуха в поруху. И как милость - вместо мук адских - будет землянка да разбитое корыто. Да утешением и поддержкой старости бедной - верный супруг всё с тем же неводом. Жили-были они ... и неведомо сколько ещё проживут.

\footnotetext{
4 Сравни: «Где дом?» в «Медном всаднике». А так же пробудившееся чувство своего родного дома у Татьяны в кабинете Онегина (7 глава романа в стихах).

5 Сравни: Татьяна сидит у окна; Евгений на сторожевом мраморном льве; Александр I застыл недвижно на балконе Зимнего дворца.

6 Сравни: Евгений первого, великого мужа-отца Отечества ругает: дескать, по его вине (прихоти самовластной воли) Град, новая Руси столица, основана под морем, а не при море, как замыслено Петром.
}

\section{Капитанская дочка \\ (Акад. Том 8. С. 323-325)}

Местоположение главного памятника ГрадаГосударства в центре площади Петровой, а также в середине композиции «Медного Всадника» (конец 1 части), совпадает с моментом кульминации борьбы сил созидания, львов сторожевых, возглавляемых Императором, с разрушительной напастью Потопа. Аналогично 7 глава «Приступ» (Белогорской крепости бунтовщиками) «Капитанской дочки» находится в середине романа (всего в нем 14 глав) и также рассказывает об одном из самых трагичных событий в судьбе героев. Именно здесь повествование насыщено интересующим нас словом, которое используется Пушкиным в значениях двух разных глаголов «стоять» и «стоить». При этом в прозаическом тексте романа их единство выступает более обособленно, чем в поэме; общих смысл глаголет в речах и действиях одних персонажей, разделенный в своих составляющих речами и действиями других.

Попрощавшись с женой и дочерью, комендант Белогорской крепости капитан Иван Кузьмич Миронов «Тут Иван Кузмич оборотился к нам, и все внимание его устремилось на неприятеля. Мятежники съезжались около своего предводителя и вдруг начали слезать с лошадей. «Теперь стойте крепко, - сказал комендант, - будет приступ...» В эту минуту раздался страшный визг и крики; мятежники бегом бежали к крепости. Пушка наша заряжена была картечью. Комендант подпустил их на самое близкое расстояние и вдруг выпалил опять. Картечь хватила в самую середину толпы. Мятежники отхлынули в обе стороны и попятились. Предводитель их остался один впереди... Он махал саблею и, казалось, с жаром их уговаривал... Крик и визг, умолкнувшие на минуту, тотчас снова возобновились. «Ну, ребята, - сказал комендант, - теперь отворяй ворота, бей в барабан. Ребята! вперед, на вылазку, за мною!»

Комендант, Иван Игнатьич и я мигом очутились за крепостным валом; но обробелый гарнизон не тронулся. «Что ж вы, детушки, стоите? - закричал Иван Кузмич. - Умирать так умирать: дело служивое!»

Призывы коменданта («стойте крепко»; «Что ж вы стоите? Оробели детушки?» Бьет час исполненья служивого долга, вперед ребята!) слышатся в начале и в конце сражения, прерываясь его визгом, шумом и грохотом, активностью, заминкой и пассивностью сражающихся. Попав в плен ни Иван 


\section{Интерпретация}

Кузьмич, ни Гринев (ни Иван Игнатьич) не сломлены духом, стоят на ногах, сбитые - поднимаются.

«В эту минуту мятежники набежали на нас и ворвались в крепость. Барабан умолк; гарнизон бросил ружья; меня сшибли было с ног, но я встал и вместе с мятежниками вошел в крепость. Комендант, раненный в голову, стоял в кучке злодеев, которые требовали от него ключей. Я бросился было к нему на помощь: несколько дюжих казаков схватили меня и связали кушаками, приговаривая: «Вот ужо вам будет, государевым ослушникам!» Нас потащили по улицам; жители выходили из домов с хлебом и солью. Раздавался колокольный звон. Вдруг закричали в толпе, что государь на площади ожидает пленных и принимает присягу. Народ повалил на площадь; нас погнали туда же.

Пугачев сидел в креслах на крыльце комендантского дома. На нем был красный казацкий кафтан, обшитый галунами. Высокая соболья шапка с золотыми кистями была надвинута на его сверкающие глаза. Лицо его показалось мне знакомо. Казацкие старшины окружали его. Отец Герасим, бледный и дрожащий, стоял у крыльца, с крестом в руках, и, казалось, молча умолял его за предстоящие жертвы. На площади ставили наскоро виселицу».

Священник, в чрезвычайной ситуации ярой вражды паствы между собой, верен пастырскому обету. Правда, вслух не печалуется за пленных ни пред разгневанной сопротивлением толпой, ни пред «Государем». Тем более не обличает тех, кто готовится свершить смертоубийство братьев во Христе. Видно, жизненный опыт, страх подсказывает ему такое поведение, «логически» существенно отличное от того, чтобы подставить обидчику и вторую щеку. (Ср. с Александром I, повелевшим своим ближайшим слугам оказывать посильную помощь терпящим от Божьей стихии подданным).

«Когда мы приближились, башкирцы разогнали народ и нас представили Пугачеву. Колокольный звон утих; настала глубокая тишина. «Который комендант?» - спросил самозванец. Наш урядник выступил из толпы и указал на Ивана Кузмича. Пугачев грозно взглянул на старика и сказал ему: «Как ты смел противиться мне, своему государю?» Комендант, изнемогая от раны, собрал последние силы и отвечал твердым голосом: «Ты мне не государь, ты вор и самозванец, слышь ты!» Пугачев мрачно нахмурился и махнул белым платком. Несколько казаков подхватили старого капитана и потащили к виселице. На ее перекладине очутился верхом изувеченный башкирец, которого допрашивали мы накануне. Он держал в руке веревку, и через минуту увидел я бедного Ивана Кузмича, вздернутого на воздух. Тогда привели к Пугачеву Ивана Игнатьича. «Присягай, - сказал ему Пугачев, - государю Петру Феодоровичу!» - «Ты нам не государь, - отвечал Иван Игнатьич, повторяя слова своего капитана. - Ты, дядюшка, вор и самозванец!» Пугачев махнул опять платком, и добрый поручик повис подле своего старого начальника».

Позорный способ казни не запятнал чести Иванов: на подобных им Державное дело стоит, мужеством встречи с самой смертью крепнет.

«Очередь была за мною. Я глядел смело на Пугачева, готовясь повторить ответ великодушных моих товарищей. Тогда, к неописанному моему изумлению, увидел я среди мятежных старшин Швабрина, обстриженного в кружок и в казацком кафтане. Он подошел к Пугачеву и сказал ему на ухо несколько слов».

Подлое наушничество предателя, его ретивое рвение выслужиться пред новым «истинным Государем Петром III» лишает Петра Андреевича последней призрачной возможности (воспользовался бы он ей или нет - другой вопрос) изменить свою участь. Как, не глядя, Пугачеву узнать в посмевшем его войску противиться дворянине единственное за всю жизнь исключение - дарителя заячьего тулупчика?

«Вешать его!» - сказал Пугачев, не взглянув уже на меня. Мне накинули на шею петлю. Я стал читать про себя молитву, принося богу искреннее раскаяние во всех моих прегрешениях и моля его о спасении всех близких моему сердцу. Меня притащили под виселицу. «Не бось, не бось», - повторяли мне губители, может быть и вправду желая меня ободрить.»

Как бог из машины, как сила рычага, переворачивающая трагическую ситуацию вверх дном, является отчаянный порыв «маленького» человека. Крепостной вступается за барина, идет против классовых интересов. Остановись проклятое, злосчастное мгновенье, замрите, разохотившиеся палачи!

«Вдруг услышал я крик: «Постойте, окаянные! погодите!..» Палачи остановились. Гляжу: Савельич лежит в ногах у Пугачева. «Отец родной! — говорил бедный дядька. - Что тебе в смерти барского дитяти? Отпусти его; за него тебе выкуп дадут; а для примера и страха ради вели повесить хоть меня старика!» Пугачев дал знак, и меня тотчас развязали и оставили. «Батюшка наш тебя милует», - говорили мне. В эту минуту не могу сказать, чтоб я обрадо- 


\section{Филология: научные исследования 4(16) • 2014}

вался своему избавлению, не скажу, однако ж, чтоб я о нем и сожалел. Чувствования мои были слишком смутны».

Ср.: жуть промежутка нестояния со всех сторон с сумасшествием Евгения: «ни зверь, ни человек, Ни то, ни сё, Ни житель света, Ни призрак мертвый...»

«Меня снова привели к самозванцу и поставили перед ним на колени. Пугачев протянул мне жилистую свою руку. «Целуй руку, целуй руку!»говорили около меня. Но я предпочел бы самую лютую казнь такому подлому унижению».

Прав Швабрин. Ох, как прав.

«Батюшка Петр Андреич! - шептал Савельич, стоя за мною и толкая меня. - Не упрямься! что тебе стоит? плюнь да поцелуй у злод... (тьфу!) поцелуй у него ручку». Я не шевелился».

В «Медном Всаднике» Пушкин передает свою в целом положительную оценку Петра Великого как строителя чудотворного взбунтовавшемуся против державца полумира Евгению и облекает ее в угрозу: «Ужо тебе». Герой не видит и не зрит умом двуглагольности сказуемого «стоит», единства - со сбоем в ударении - поэзии и прозы. У Савельича же в критический момент возврата к казни его господина два «наших» слова расположены совсем рядом друг с другом, а их единство сдобрено комичной полуоговоркой.

«Пугачев опустил руку, сказав с усмешкою: «Его благородие, знать, одурел от радости. Подымите его!» Меня подняли и оставили на свободе. Я стал смотреть на продолжение ужасной комедии».

В тупике клятвоцелования «Петр III» мигом смекнул, как спасти тезку без урона своего царского сана. Он с усмешкой объявляет верность Гринева присяге Екатерине II безумием и велит поднять его с колен (привести внешнее в соответствие с внутренним.

Общий ужас продолжился в смерти Василисы Мироновой: без погибшего мужа нет ей места на земле, свет их жизни стоял заедин и угас разом.

«Стоит» в значении посюсторонней земной меры мира стихий, ее высшей степени устроения, «скачком» преобразуется в потустороннюю метафизику небесного до-СТО-инства, на-СТО-стоящего в неколебимой вышине. Смысл слова (из тех же букв и в той же их последовательности) пульсирует в значениях двух глаголов то внутри возможностей стихосложения, то за ее пределами, в прозе. Похоже на коня, заскочившего на край вершины, окруженной бездной: высота иначе недостигаемая, поко- ренная неимоверной мощью и с превеликими тяготами удерживаемая от обвала с обрыва. Заскочить на гордом огненном коне туда и там держаться дано редчайшим избранникам, мощным Властелинам судьбы. Согласно Пушкину, дано Петру I Великому, не дано Евгению.

Русскоязычная поэзия в лице Пушкина совершила чудо-чудное: зафиксировала, в одном слове высказала одновременно противоречивое единство глагольных значений неподвижности и подвижности, синтезировав их в смысл (целость) вечного движения.

Но здесь же обнаруживаются и принципиальные границы стихосложения. Взволнованность смысла поэмы, слов авторской идеи в ней выламывается из размеренного русла стихоткачества, принятый в «Медном Всаднике» ямб сбивается на хорей. Эта подмена «высокой поэзии» на «низкую прозу» осуществляется не где-то на периферии, захолустной окраине произведения, а в наиважнейшем ее слове «стоит», находящемся в его центре. Это - опора строительства Града-Государства, порядка уменьшающего хаотичность стихий в их спонтанности. Это происходит в момент кульминации противостояния, когда злоба разрушения отбросила сотворенное на последнюю границу НЕбытия, равного Ничто.

На мой взгляд, Александр Сергеевич отчетливо сознавал необходимость, вернее, неизбежность подмены поэтической речи прозаической. Свидетельством тому служит подзаголовок поэмы. «Петербургская повесть». О неслучайности данной проблемы и возможности ее «непротиворечивого» выражения в прозе (двумя словами, каждое из которых строго однозначно связано с одним - своимглаголом) говорит его поэтическая проза в «Капитанской дочке», написанной три года спустя.

Может быть, обнаружение «роковой воли» Поэзии, неизбежности ради отчетливости и полноты смысла произведения в целом «наводнения» ямба прозой в ключевом слове, способствовало выводу Пушкина об их равноценности? Или даже о предпочтительности прозы в словесном выражении мыслей мироустройства? Поэм (произведений большого поэтического жанра) Поэт после «Медного Всадника» не написал. Три оставшиеся ему года жизни оставляют эту тему без его категорического ответа. Впрочем, открытость темы после предложенного автором решения в произведении (или, более явно, ряда решений в нескольких произведениях), ее неизбывная, вопрошающая собеседни- 


\section{Интерпретация}

ков проблемность - очень характерна для живого Александра Сергеевича. Чтобы не быть возвышенно пустословным, достаточно вспомнить хоть один подходящий случай. На мой взгляд, весьма показательный пример содержится в диалоге Моцарта и Сальери, где каждый говорит о несовместности гения и злодейства в облаке вопросов, но в антагонистически потустороннем друг другу смысле.

В 1834 г. 20-летнюю годовщину победы над Наполеоном, вступления русских войск в Париж в честь этого наивысшего достижения правления Александра I в центре Дворцовой площади СанктПетербурга по проекту архитектора Огюста Монферрана «воздвигли Александровскую колонну цельный гранитный столб с фигурой ангела на вершине. Высота памятника - 47,5 метра. Тогда это было самое грандиозное сооружение такого рода в мире: выше колонны Траяна в Риме, выше Вандомской колонны в Париже» ${ }^{7}$.

Камер-юнкер А.С. Пушкин не присутствовал на торжествах открытия памятника самых славных дел эпохи Александра I. Поэт уехал из города за несколько дней до проведения важнейшего официального мероприятия. Внешне его пренебрежение придворным этикетом выглядит как рецидив юношеского молодечества, свойственного многим лицеистам первого выпуска в первое время после Лицея, но неуместное взрослому человеку, степенному служащему государству, отцу семейства. По сути же «побег» с официоза - протест против утверждения в общественном сознании и закрепления в видимом (чувственном) восприятии «простых», малокультурных людей превосходства заслуг Александра I перед Петром Великим. Боле обще - Пушкин протестует против оценки достигнутого к середине 1830-х годов Россией уровня Благого Просвещенья. До гладко отполированной, прямо устремленной в высь, самой высокой в мире и увенчанной ангелом хранителем Культуры Созидания ох, как далеко; лет эдак через 500, по расчисленью философиче- ских таблиц, можно будет хвалиться, не отрываясь сильно от фактов, что благое Просвещенье вошло в быт, плоть и кровь, думы и нравы страны.

Написанный в предыдущем 1833 г. и запрещенный к напечатанию Николаем I «Медный Всадник» давал Поэту весомые основания для неприятия официозно-государственной оценки российской истории и ее нынешнего состояния. Поэма-повесть идейно выше и богаче, истиннее воплощает то, какова Россия. Высота, достигнутая не без подъема на дыбы коня (государства), в сверхнапряжении чрезмерно давящего на неотшлифованный, едва обработанный гранитный постамент (податные сословия), тяжело-звонкое скаканье Медного Всадника - такой сложно-противоречивой, тяжким трудом удерживаемой в равновесии и нужном направлении предстает Империя в пушкинском произведении. И сам Поэт «главою непокорной» воздвигнутого себе нерукотворного памятника живее, созидательнее, выше столба Александра I на Дворцовой площади, хотя и не увенчан Ангелом (да и при жизни его так не называли, не льстили в отличие от царствующего тезки).

Выше ли Пушкин Петра? Петра, вставшего через сто лет после смерти на защиту своего творения в грозный час потопа, вздыбившего огненного коня у бездны на краю и победившего, явившего тщету злобы пред на-СТО-стоящим? Не выше. Себя Поэт ставил и склонённым перед гробницею святой и наравне с орлами, парящими над кавказскими вершинами. Со всем земным и над ним. И за пределами изменчивого подлунного мира, где вышина непоколебима. В ней нет измерения «ниже-выше», только вечнотворящая жизнь.

«Кальдерон, Шексп.(ир) и Расин стоят на высоте недосягаемой - и их произведения составляют вечный предмет наших изучений и восторгов» (Аккад. XI с. 177). Сказанное Пушкиным о своих настоящих собратьях по служению Музам в полной мере относится и к его жизнетворчеству.

\section{Список литературы:}

1. Алексеев М.П. Пушкин и проблема вечного мира // Пушкин. Сравнительно-исторические исследования / Под ред. Г.В. Степанов, В.Н. Баскаков. Л., 1984.

2. Альтшуллер М.Г. Между двух царей: Пушкин. 1824-1826. СПб.: Академический проект, 2003.

3. Аринштейн Л.М. Николаевский цикл Пушкина // Пушкин: непричесанная биография. М.: Изд. дом «Муравей», 1999.

4. Архангельский А.Н. Стихотворная повесть А.С. Пушкина «Медный всадник». М.: Высшая школа, 1990.

5. Ахматова Анна. О Пушкине. Л., 1977.

7 Гордин А., Гордин М. Путешествие в пушкинский Петербург. Ленинград: Лениздат, 1983. С. 9. 


\section{Филология: научные исследования 4(16) • 2014}

6. Бицилли П. Пушкин и Николай I // Московский пушкинист. Вып. III. М.: Наследие, 1996.

7. Благой Д.Д. Мастерство Пушкина. М., 1955.

8. Вацуро В.Э. Пушкин и проблемы бытописания в начале 1830-х годов // Пушкин: Исследования и материалы / АН СССР. Ин-т рус. лит. (Пушкинский дом). Т. 6. Л.: Наука, 1969.

9. Гордин А., Гордин М. Путешествие в пушкинский Петербург. Ленинград: Лениздат, 1983.

10. Измайлов Н.В. «Медный всадник» А.С. Пушкина. История замысла и создания, публикации и изучения // Пушкин А.С. Медный всадник. Л., 1978. С. 147-265.

11. Красухин Г.Г. Доверимся Пушкину: Анализ пушкинской поэзии, прозы и драматургии. М.: Флинта, Наука, 1999.

12. Летопись жизни и творчества Александра Пушкина. В 4-х тт. / Сост. Н.А. Тархова. М.: Слово, 1999.

13. Листов В.С. «История Петра» в биографии и творчестве А.С. Пушкина // Пушкин А.С. История Петра. М.: Языки русской культуры, 2000.

14. Лотман Ю.М. Пушкин: Биография писателя; Статьи и заметки, 1960-1990; «Евгений Онегин»: Комментарий. СПб.: Искусство-СПб, 1995.

15. Макаровская Г.В. «Медный всадник»: Итоги и проблемы изучения. Саратов: Изд-во Саратовского гос. ун-та, 1978

16. Макогоненко Г.П. Творчество А.С. Пушкина в 1830-е годы (1833-1836). Л.: Художественная литература, 1982.

17. Мейер П. Как сделан «Медный всадник» / Пер. с англ. Н. Сосны. М., 2005.

18. Немировский И.В. Библейская тема в «Медном всаднике» // Немировский И.В. Лирика Пушкина и проблема публичного поведения поэта. СПб.: Ги-перион, 2003.

19. Немировский Игорь. Зачем был написан «Медный всадник» // Журнальный клуб Интелрос «НЛО». 2014. № 126.

20. Осповат А.Л., Тименчик Р.Д. «Печальну повесть сохранить..»: Об авторе и читателях «Медного всадника». М.: Книга, 1985.

21. Пумпянский Л.В. «Медный всадник» и поэтическая традиция XVIII века. М.: Языки русской культуры, 2000.

22. Пушкин А.С. Полн. собр. соч.: В 17-и тт. М.; Л.: Изд-во АН СССР, 1937-1949.

23. Пушкин в воспоминаниях современников. СПб., 1998.

24. Пушкин в русской философской критике. Конец XIX-XX век. М., СПб.: Университетская книга, 1999.

25. Пушкинская энциклопедия. Произведения. Вып. 1. А - Д. Нестор - История. СПб., 2009.

26. Рудаков С.Б. Ритм и стиль «Медного Всадника» // Пушкин. Исследования и материалы. Т. IX. Л., 1979.

27. Медный всадник: композиция конфликта // Седакова О.А. Проза. М.: Эн Эф Кью/Ту Принт, 2001.

28. Словарь языка Пушкина: в 4-х тт. / Под ред. В.В. Виноградова. 2-е изд. М.: Азбуковник, 2000.

29. Топоров В.Н. Петербург и «Петербургский текст русской литературы». Введение в тему // Топоров В.Н. Миф. Ритуал. Символ. Образ: Исследования в области мифопоэтического: Избранное. М.: Прогресс-Культура, 1995. С. 259367

30. У Уаённая любовь Пушкина: сборник / Под ред. Р.В. Иезуитова, Я.Л. Левкович. СПб.: Академический проект, 1997.

31. Ц Цявловский М.А. Статьи о Пушкине. М., 1962.

32. Черейский Л.А. Пушкин и его окружение. Л.: Наука, 1988.

33. Эткинд Е.Г. Многосмысленность повести-поэмы «Медный всадник» // Божественный глагол. Пушкин, прочитанный в России и Франции. М.: Языки русской культуры, 1999. С. 468-480.

\section{References (transliteration):}

1. Alekseev M.P. Pushkin i problema vechnogo mira // Pushkin. Sravnitel'no-istoricheskie issledovaniya / Pod red. G.V. Stepanova, V.N. Baskakova. L., 1984.

2. Al'tshuller M.G. Mezhdu dvukh tsarei: Pushkin. 1824-1826. SPb.: Akademicheskii proekt, 2003.

3. Arinshtein L.M. Nikolaevskii tsikl Pushkina // Pushkin: neprichesannaya biografiya. M.: Izd. dom «Muravei», 1999.

4. Arkhangel'skii A.N. Stikhotvornaya povest' A.S. Pushkina «Mednyi vsadnik». M.: Vysshaya shkola, 1990.

5. Akhmatova Anna. O Pushkine. L., 1977.

6. $\quad$ Bitsilli P. Pushkin i Nikolai I // Moskovskii pushkinist. Vyp. III. M.: Nasledie, 1996.

7. Blagoi D.D. Masterstvo Pushkina. M., 1955.

8. Vatsuro V.E. Pushkin i problemy bytopisaniya v nachale 1830-kh godov // Pushkin: Issledovaniya i materialy / AN SSSR. In-t rus. lit. (Pushkinskii dom). T. 6. L.: Nauka, 1969.

9. Gordin A., Gordin M. Puteshestvie v pushkinskii Peterburg. Leningrad: Lenizdat, 1983.

10. Izmailov N.V. «Mednyi vsadnik» A.S. Pushkina. Istoriya zamysla i sozdaniya, publikatsii i izucheniya // Pushkin A.S. Mednyi vsadnik. L., 1978. S. 147-265.

11. Krasukhin G.G. Doverimsya Pushkinu: Analiz pushkinskoi poezii, prozy i dramaturgii. M.: Flinta, Nauka, 1999.

12. Letopis' zhizni i tvorchestva Aleksandra Pushkina. V 4-kh tt. / Sost. N.A. Tarkhova. M.: Slovo, 1999.

13. Listov V.S. «Istoriya Petra» v biografii i tvorchestve A.S. Pushkina // Pushkin A.S. Istoriya Petra. M.: Yazyki russkoi kul'tury, 2000.

14. Lotman Yu.M. Pushkin: Biografiya pisatelya; Stat'i i zametki, 1960-1990; «Evgenii Onegin»: Kommentarii. SPb.: Iskusstvo$\mathrm{SPb}, 1995$.

15. Makarovskaya G.V. «Mednyi vsadnik»: Itogi i problemy izucheniya. Saratov: Izd-vo Saratovskogo gos. un-ta, 1978.

16. Makogonenko G.P. Tvorchestvo A.S. Pushkina v 1830-e gody (1833-1836). L.: Khudozhestvennaya literatura, 1982. 


\section{Интерпретация}

17. Meier P. Kak sdelan «Mednyi vsadnik» / Per. s angl. N. Sosny. M., 2005.

18. Nemirovskii I.V. Bibleiskaya tema v «Mednom vsadnike» // Nemirovskii I.V. Lirika Pushkina i problema publichnogo povedeniya poeta. SPb.: Gi-perion, 2003.

19. Nemirovskii Igor'. Zachem byl napisan «Mednyi vsadnik» // Zhurnal'nyi klub Intelros «NLO». 2014. № 126.

20. Ospovat A.L., Timenchik R.D. «Pechal'nu povest' sokhranit'...»: Ob avtore i chitatelyakh «Mednogo vsadnika». M.: Kniga, 1985.

21. Pumpyanskii L.V. «Mednyi vsadnik» i poeticheskaya traditsiya XVIII veka. M.: Yazyki russkoi kul'tury, 2000.

22. Pushkin A.S. Poln. sobr. soch.: V 17-i tt. M.; L.: Izd-vo AN SSSR, 1937-1949.

23. Pushkin v vospominaniyakh sovremennikov. SPb., 1998.

24. Pushkin v russkoi filosofskoi kritike. Konets XIX-XX vek. M., SPb.: Universitetskaya kniga, 1999.

25. Pushkinskaya entsiklopediya. Proizvedeniya. Vyp. 1. A - D. Nestor - Istoriya. SPb., 2009.

26. Rudakov S.B. Ritm i stil” «Mednogo Vsadnika» v izd.: Pushkin. Issledovaniya i materialy. T. IX. L., 1979.

27. Sedakova O.A. Mednyi vsadnik: kompozitsiya konflikta // Sedakova O.A. Proza. M.: En Ef K'yu/Tu Print, 2001.

28. Slovar' yazyka Pushkina: v 4-kh tt. / Pod red. V.V. Vinogradova. 2-e izd. M.: Azbukovnik, 2000.

29. Toporov V.N. Peterburg i «Peterburgskii tekst russkoi literatury». Vvedenie v temu // Toporov V.N. Mif. Ritual. Simvol. Obraz: Issledovaniya v oblasti mifopoeticheskogo: Izbrannoe. M.: Progress-Kul'tura, 1995. S. 259-367.

30. Utaennaya lyubov' Pushkina: sbornik / Pod red. R.V. Iezuitova, Ya.L. Levkovich. SPb.: Akademicheskii proekt, 1997.

31. Tsyavlovskii M.A. Stat'i o Pushkine. M., 1962.

32. Chereiskii L.A. Pushkin i ego okruzhenie. L.: Nauka, 1988.

33. Etkind E.G. Mnogosmyslennost' povesti-poemy «Mednyi vsadnik» // Bozhestvennyi glagol. Pushkin, prochitannyi v Rossii i Frantsii. M.: Yazyki russkoi kul'tury, 1999. S. 468-480. 